\begin{tabular}{|c|c|c|}
\hline \multirow{2}{*}{\multicolumn{2}{|c|}{$\begin{array}{ll}\text { DE } & \text { DE GRUYTER } \\
& \text { OPEN }\end{array}$}} & ECONOMIC THEMES (2018) 56(1): 57-78 \\
\hline & & DOI 10.2478/ethemes-2018-0004 \\
\hline
\end{tabular}

\title{
IDENTIFICATION AND ANALYSIS OF KEY BUSINESS PROCESS MANAGEMENT FACTORS
}

\section{Aleksandra Stoiljković Ranđelović}

\author{
PhD student, University of Niš, Faculty of Economics, Republic of Serbia \\ $\triangle$ aleksandras.randjelovic@gmail.com
}

\section{Radenko Milojević}

University of Niš, Faculty of Economics, Republic of Serbia

$\bowtie$ radenko.milojevic@eknfak.ni.ac.rs

\section{Marija Radosavljević}

University of Niš, Faculty of Economics, Republic of Serbia

$\triangle$ marija.radosavljevic@eknfak.ni.ac.rs

UDC

005.83

Original scientific paper

Received: 02.02.2018 Accepted: 02.04.2018
Abstract: Under the conditions of ever-increasing competition in the market, companies can reach a competitive advantage only with flexible offer of quality superior and cheaper products/services. In order to achieve this, companies must carry out innovative and effective business processes and manage them appropriately. In this regard, it is important to identify the factors that may be considered critical for improving business process management. The aim of this paper is to identify and analyse key business process management factors, on the example of the electronic industry. The research results show that the factors that are usually accepted as the most important for increasing the maturity of business process management are not recognised as dominant in the electronic industry. One of the findings of the survey reveals, as the main lagging factors, four of the six most important factors for the successful implementation of business processes. Based on results of the research, Managing employees has been detected as the most important maturity factor for companies from the electronic industry; hence, the suggestion is further improvement within this field.

Keywords: process orientation, business process management, maturity factors, and electronic industry

JEL classification: L25, M12 


\section{Introduction}

The frequent changes that occur as the result of a high degree of adaptability of business systems, lead to the creation of new or modified organisational structures of high flexibility driven by users' requirements (Adamides \& Karacapilidis, 2006). Usually, changes include process orientation. In process-oriented companies the focus has changed from business functions to business processes, with emphasised relation with customers and suppliers (Andersen, 1999). It is important to emphasise that process orientation is not synonymous with process organisational structure (Bosilj Vukšić et al., 2006). It represents an understanding the flow of business and is only the first step towards a process organisational structure.

Changes in the market indicate the need that companies constantly analyse and improve business processes, but also to find ways for efficient coordination of integrated business processes, providing at the same time value for customers and rational consumption of resources. Business Process Management (BPM) is a management discipline aimed at describing and managing the business processes in an organisation (Koster, 2009). The goal of BPM is for the organisations' objectives to be achieved by aligning the business processes with the strategy and to continually improve them.

The implementation of BPM is a very complex and time-consuming process that requires great effort, resources, discipline and commitment. Many companies have tried to change their business in compliance with a process orientation, but only few have managed to completely integrate their business functions into end-to-end processes (Bandara et al., 2009). Consequently, many BPM projects are unsuccessful in practice (Trkman, 2009). At the same time, successful implementation is a prerequisite for the benefits of this concept (Štemberger et al., 2009).

Since BPM is a multidisciplinary concept, its success depends on different factors (Bandara et al., 2009). Many research studies, aiming to find and to explore the success and failure factors of BPM implementation, have already been conducted, but the area remains an interesting research topic (Alibabaei et al., 2010).

In order to implement BPM properly, it is necessary to identify key processes and key success factors. This is the precondition for creating the matrix of processes and factors, which can help managers to identify the influence of factors to the processes. For this reason, the identification of BPM factors deserves special attention of managers, and especially process owners. Companies that have adopted process approach become aware of the power of their processes and the importance of providing the quality of their products, which, together with continuous improvement, ultimately leads to increased satisfaction of all stakeholder groups, but also to the success of the organisation (Chen, 2001).

The study presented in this paper aims to explore the state of business processes management maturity of the companies in the electronic industry. The 
purpose of this paper is to identify and analyse the achieved level of development of the maturity factors, on the example of electronic industry.

\section{Business process management conditionality: Factors' identification}

In line with changes in the environment, there are also changes in managing, and one of very important changes in the last few decades concerns business processes. Their importance has been changing during the last few decades, but it is certainly that doing business in the 21st century will not be possible without process orientation. As Harmon (2014) noted, all contemporary organisational structures, to a greater or lesser extent, emphasise the importance of business processes. Business process management is becoming an important part of organisations' operations (Lahajnar \& Rožanec, 2016). Jeston and Nelis (2014) define BPM as achieving goals of an organisation through management, improvement, and control of essential business processes. According to Weske (2007) business process management includes concepts, methods, and techniques to support the design, administration, configuration, enactment, and analysis of business processes.

As part of these changes, it is possible to identify factors that influence the implementation of business process management. Dealing with this issue for some time, authors concluded that the most organisations identify around 7 key business processes and between 6 and 16 factors, critical for business process management. Many researchers are focusing on the six key factors of BPM, which include strategic alignment, culture and leadership, people, governance, methods and information technology (Fisher, 2004; Melenovsky \& Sinur, 2006). Bandara et al. (2009) introduce nine success factors, namely: culture, leadership, communication, information technology, strategic alignment, people, project management, performance measurement and methodology. Ravesteyn and Batenburg (2010) conducted a survey among 39 Dutch consultants, developers and end-users of BPM-systems and found that communication, involving the right people in the project and making sure that there is support from top management and governance are the critical factors.

It is important to say that organisations should consider different factors as well as the links between them, rather than putting emphasis on only some of them. One study (Bai \& Sarkis, 2013) found a number of direct and indirect relationships among the factors. According to the results of this study the four most important factors include: strategic alignment, top management support, project management and collaborative environment. Based on the studies of others authors in the field of process management (Jarrar et al., 2000; Ravesteyn \& Versendaal, 2007; Trkman, 2010; Vom Brocke \& Rosemann, 2010; Jeston \& Nelis, 2014), but also on the basis of the authors' experience, 16 business process management factors have been identified, and they are: 
- Strategic alignment,

- IT investment,

- Process measurement,

- Managing employees,

- Organisational changes,

- Appointing process owners,

- Managers' commitment,

- Continuous improvement,

- Business culture,

- Information technology,

- Methods,

- Employees' specialisation,

- Focus on customers and their requirements,

- Standardisation of processes,

- Implementation of proposed changes,

- Cooperation with suppliers.

Strategic alignment - According to Rosemann and de Bruin (2006), strategic alignment of BPM has to enhance the linkages that connect organisational priorities and company processes in order to achieve its business objectives. Although business process management assumes focus on realisation and improvement of everyday activities, it does not mean that it is separated from the company's strategy. On the contrary, business process management has to be balanced with the strategy, since otherwise the efficiency of business processes will not lead to the accomplishment of company's objectives and it will be useless. Therefore, some authors consider the relationship between strategy and operations function as crucial (Rhee \& Mehra, 2006).

IT investment - Performing tasks in today, dynamic environment cannot be imagined without information technology. For this reason, investment in IT can be observed as a necessary condition for providing the competitive advantage, in the same way as other non-material resources are. The required level of IT investment depends on company's strategy, other organisational resources, which interact with IT and on the external environment (Duh et al., 2006; Melville et al., 2004). Certainly, IT technology is not enough by itself for gaining the competitive advantage, but it can contribute certainly to the improvement of the internal environment where all resources necessary for process realisation are connected and balanced and where managers must reengineer their core processes from a customer perspective (Terziovski et al., 2003).

Process measurement - According to process approach, it is very important to define critical control points during the process realisation, at least as important as to measure the characteristics of the process output, after the process has been finished. This claim comes from the fact that measurement during the process 
realisation can help managers to identify the mistakes and errors while process still lasts and to correct them before additional resources are used for their further processing. In the meantime, it is important that the obtained measurement results are used as feedback for improving process efficiency (Hassan, 2009).

Managing employees - Contemporary business is characterised by the perception of employees as the most valuable assets of the company. Starting from the fact that their knowledge, skills, communication largely determine the success or failure of the company, the management of employees is the most important and the heaviest part of the work of the managers. Empowering of employees and appreciating their ideas and suggestions are significant motivational tools, which are often crucial for the successful business process management. Empowering employees to make decisions independently can help make operations easier and faster (Trkman \& McCormack, 2010).

Organisational changes - Usually authors who research the field of process management agree that it is not necessary to make changes in the organisational structure. But, potential problems with an inadequate organisation are reflected in the increase in costs, inconsistency in the execution of functional decisions between processes, and general decline in the efficiency (Silvestro \& Westley, 2002). However, although the organisational units may still be separated formally, their employees have to make mutual communication more intensive in order to avoid the silo effects. This is in line with the attitude of Leavitt (2005), according to whom hierarchies must be changed so that employees perform their tasks more efficient.

Appointment of process owners - Identification of process owner is one of the most important issues of the implementation of the process approach. The existence of the process owner represents most noticeable difference between a process company and a traditional one (Hammer \& Stanton, 1999). This is also the issue critical for providing the link between the organisational units that perform activities included in the same process. The process owner is in charge for taking care of the process from the beginning till its end and for accomplishing the defined objectives. According to Hammer and Stanton (1999), the owner of the process must have a constant role, real responsibility and authority in making decisions on process design, performance measurement, as well as training and improvement of employees who perform them.

Managers' commitment - Although the implementation of business process management often requires the engagement of appropriate professionals, the support and commitment of managers is very important. Responsibility of engaged experts cannot be delegated, so managers have to be completely involved in process management.

Continuous improvement - Striving to perfection has to be a light motive for all companies wishing to sustain achieved comparative advantage or trying to reach it. 
This factor is emphasized as very important in the most of process management models. It assumes process observation, measurement and analysis, and based on the facts, improvement of process aspects that are main limitation for increasing process efficiency or effectiveness. Continuous improvements are based on encouraging the organisational culture and formal structure (Trkman, 2010). The top management must be the main support while process owners should be the main drivers for popularisation of continuous improvement (Savolainen, 1999).

Business culture - Business culture is a manifestation of attitudes, values and traditions in a company. Culture is often referred to as a key driver of BPM initiatives (Rosemann \& vom Brocke, 2010), representing both a source of failure and success in BPM initiatives (Melenovsky \& Sinur, 2006). In line with the fact that in the modern business environment the only constant is change, continuous adjustment to changes, or initiating changes to improve business processes must become an everyday task of all employees (vom Brocke \& Schmiedel, 2011).

Information technology - Information technology includes the software, hardware and information management systems that support the process activities (Melenovsky \& Sinur, 2006). Contemporary companies are aware of the importance of IT and do not ask the question of whether it is profitable to implement IT, but are in the dilemma about the technology they should choose. There are an increasing number of software packages related to business process management. However, it has to be emphasized that IT itself cannot bring any competitive advantages (Terziovski et al., 2003).

Methods - Rosemann \& vom Brocke (2010) defined methods, in the context of BPM, as the set of tools and techniques that support and enable activities along the process lifecycle and within enterprise-wide BPM initiatives. Different kinds of methodologies have been developed to help organisations manage their business processes. Some can be used in any organisation. For example, many organisations have tried some process improvement methods (Six Sigma, Lean...) or new technology, such as Business Activity Monitoring, Service Oriented Architectures (Garimella et al., 2008).

Employees' specialisation - It is clear that employees' specialisation is very important for increasing process efficiency, because they can perform their tasks faster and more accurately. However, narrow specialisation may be an obstacle for flexibility, which is also important for providing sustainable competitiveness in modern conditions. For those reasons, it is necessary to provide optimal balance between employees that are specialist and those who are generalists (Mulyar \& van der Aalst, 2005), primary bearing in mind processes and activities critical for providing customers' satisfaction (Reijers \& Mansar, 2005).

Focus on customers and their requirements - Connection with customers is reflected in need to identify the ones that represent the target group for the company and then to define and specify their needs. This kind of specification is 
base for process standardisation and setting up the measurement system. Especially are important critical to quality customers' requirements, because the company has to provide them if it does not want to disappoint its customers. Customers' satisfaction is precondition for their loyalty, so the companies' task is to continuously analyse the level of their satisfaction and their suggestions for the improvement. In fact, customers play a crucial role both at the beginning and at the end of a business process, providing valuable input for the business process and assessing the quality of the output (vom Brocke \& Schmiedel, 2011).

Standardisation of processes - Standardisation is a key condition for providing the reliability of the process; It assumes identification of the activities and tasks and resources for their performing, providing at the same time, their optimal combination and consistency in their usage. If it is based on customers' demands, then standardisation may be observed as a condition for providing quality of final outputs. Given that processes are carried out with the respect of specifications and rules, this means that BPM systems are positively connected to standardisation (Küng \& Hagen, 2007). However, sometimes standardisation leads to impairment of innovation and performance. In such processes, companies should avoid setting rigorous rules (Benner \& Tushman, 2003; Hall \& Johnson, 2009).

Implementation of proposed changes - Very important factor of business process management success is company's capability to implement necessary changes. For the success of this process, it is necessary to provide support from the employees, the ones that may be considered as change agents and who will act as promoters of the change and advocates of the process manager. Also, middle management is significant to help employees in transition (Herzig \& Jimmieson, 2006).

Cooperation with suppliers - Bearing in mind that quality of inputs determines the quality of processes realisation and, consequently, the quality of outputs, the relationship with suppliers is equally important as relationship with customers. For that reason, it is necessary that company demands from its suppliers to adopt the same business philosophy and to implement the same process approach. In this way, company extends the process management philosophy into supply chain, extending, in that way, the base for sources of competitive advantage. There are different forms of connection from a competitive relationship to a partnership relationship. Today, companies are increasingly cooperating with their suppliers and include them in the development of new products (Cantista \& Tylecote, 2008; Valle \& Vazquez Bustelo, 2009). Inclusion of suppliers into innovation process is especially important today when customers' demands are constantly changing and when the product life is shortened. Therefore, the role of suppliers is important in ability of company to innovate (Roberts, 2001).

One of the most explored and analysed model for business process maturity management - model formulated by Rosemann and de Bruin (2005), based on the Delphi study, suggests that the critical factors for the successful implementation of 
business processes, are: strategic alignment, process management, employee management, methods, information technology, and culture. The maturity of process management is determined exactly by the quality and the presence of these factors (Radosavljevic, 2015). Those six factors will be used for a comparison with the most significant factors of business process management maturity in the research presented in this paper.

\section{Research framework}

Previously introduced factors represent the framework for the researching conditionality of the business process management in the Republic of Serbia. The electronic industry has been selected as a basis for this research because it's increased growth due to the effects of the globalisation process and the inflow of foreign capital into our country, as well as its contribution to the economy. This study aims to explore the state of business processes management maturity of the companies in the electronic industry and the achieved level of development of the maturity factors. The research was conducted in November 2017.The research involved data collection including survey and interviews. The survey questionnaire was used as a research technique.

The objective of the research has been identification of the key factors of business process management maturity in the Republic of Serbia. Therefore, the research has been led by the following hypotheses, formulated based on the research of other authors and the pre-research conducted in September 2017:

- H1: Factors that are stated as critical for increasing business process management maturity are recognised as the most important in the electronic industry, based on the observed sample,

- H2: The main lagging factors are Managing employees and Information technology,

- H3: All of the observed factors influence business process management maturity.

The questionnaire that has used consists of two parts. Within the first part of the questionnaire, the questions aimed to collect the basic data about the companies and the information about the interviewed managers (the function of the interviewed manager, the gander, the years of age, and the years of work in business process management ...).

The second part of the questionnaire included two segments. The objective of the first segment was to determine, based on the respondents' answers, in which state - silos, tactical integration, process orientation, optimized company, intelligent network, the companies were. The second segment consists the questions that aim to identify the maturity level of each of the business process management factors (Strategic alignment, IT investment, Process measurement 
(Process management), Managing employees, Organisational changes, Appointing process owners, Managers' commitment, Continuous improvement, Business culture, Information technology, Methods, Employees' specialisation, Focus on customers and their requirements, Standardisation of processes, Implementation of proposed changes, Cooperation with suppliers). Based on the processing of these data, one can notice the level of development of each factor individually, and determine whether some of the factors lag behind in comparison with others. By revealing factors that are at a lower level of maturity compared to others, appears the need to put emphasis on their correction and improvement.

The data were collected by surveying the top managers of the companies. For the purpose of analysis, a scale ranging from 1 to 5 has been used, where 1 means that the claim is completely incorrect, while 5 means that the claim is completely correct.

The data collected were processed with the software SPSS (Statistical Package for the Social Sciences). In order to test presented hypotheses, the authors used descriptive statistics, as well as regression analysis, correlation analysis and cluster analysis.

\section{Research results and discussion}

The research of the achieved maturity level, conducted in previous years (Radosavljevic, 2015), suggests the use of the following interval groups, which represent different levels of maturity:

- Up to 2.50 - the second level of maturity,

- From 2.51 to 3.50 - the third level of maturity,

- From 3.51 to 4.50 - the fourth level of maturity and

- Over 4.51 - the fifth level of maturity.

Starting from such interval groups, the factors' maturity level can be determined. For that cause, the collected data from the questionnaire are processed and the results of descriptive statistics are shown in Table 1.

According to the obtained results, it may be said that all factors are at the fourth level of development. However, this result has to be accepted with reserve, due to the (positive) subjectivity of the interviewed managers.

The obtained average marks and accepted interval groups, show that there is no factor which has reached the fifth level of maturity. The most developed maturity factors of the observed companies are Standardisation of processes (4.4815), Continuous improvement (4.3704) and Employees' specialisation (4.2963). Higher level of development also exists for factors such as Methods (4.2593), Cooperation with suppliers (4.2222) and Managing employees (4.1481). Comparing the factors that are most often mentioned as the dominant with most developed factors in the 
observed companies, it is discovered that the only ones that appear few times are factors Methods and Managing employees only. The factors that are usually accepted as the most important for increasing business process management maturity are not recognised as dominant in the electronic industry. In this sense, it can be said that the first hypothesis should be rejected.

Table 1. Descriptive statistics

\begin{tabular}{|l|c|c|c|c|c||}
\hline & $\mathbf{N}$ & Minimum & Maximum & Mean & $\begin{array}{c}\text { Std. } \\
\text { Deviation }\end{array}$ \\
\hline Strategic alignment & 27 & 1.00 & 5.00 & 3.5926 & 1.11835 \\
\hline IT investment & 27 & 2.00 & 5.00 & 4.0370 & .80773 \\
\hline $\begin{array}{l}\text { Process measurement } \\
\text { (Process management) }\end{array}$ & 27 & 2.00 & 5.00 & 3.8519 & 1.09908 \\
\hline Managing employees & 27 & 2.00 & 5.00 & 4.1481 & .94883 \\
\hline Organisational changes & 27 & 2.00 & 5.00 & 4.0741 & .99715 \\
\hline Appointing process owners & 27 & 1.00 & 5.00 & 3.5926 & 1.21716 \\
\hline Managers' commitment & 27 & 2.00 & 5.00 & 3.6296 & .96668 \\
\hline Continuous improvement & 27 & 3.00 & 5.00 & 4.3704 & .74152 \\
\hline Business culture & 27 & 2.00 & 5.00 & 3.8148 & .92141 \\
\hline Information technology & 27 & 2.00 & 5.00 & 3.7778 & .93370 \\
\hline Methods & 27 & 2.00 & 5.00 & 4.2593 & .94432 \\
\hline Employees' specialisation & 27 & 3.00 & 5.00 & 4.2963 & .82345 \\
\hline $\begin{array}{l}\text { Focus on customers and their } \\
\text { requirements }\end{array}$ & 27 & 2.00 & 5.00 & 4.0370 & .89792 \\
\hline Standardisation of processes & 27 & 2.00 & 5.00 & 4.4815 & .89315 \\
\hline $\begin{array}{l}\text { Implementation of proposed } \\
\text { changes }\end{array}$ & 27 & 2.00 & 5.00 & 4.0461 & .8423 \\
\hline Cooperation with suppliers & 27 & 1.00 & 5.00 & 4.2222 & 1.01274 \\
\hline \hline
\end{tabular}

Source: Authors' calculation

There are few main lagging factors which should be improved and developed. Based on results the factors least developed are Strategic alignment (3.5926), Appointment of process owners (3.5926), Managers commitment (3.6296), Information technology (3.7778), Business culture (3.8148) and Process management (3.8519). Those results show that for further increasing of process management maturity very important things are missing and they are strategic approach to process orientation, intensive usage of IT, business culture change and improvement of process management. Bearing in mind that those four factors are stated as four of six the most important factors it may be said that they will represent the significant limitation for process orientation spreading through the observed companies. Also, it can be noticed that the main lagging factor in the 
electronic industry are not Managing employees, on the contrary, this is one of the six dominant factors. But, maturity factor Information technology is one of the factors weakest developed in the observed companies. It means the second hypothesis is partially accepted.

Table 2: Comparison of business process management maturity factors

\begin{tabular}{|c|c|c|c|}
\hline $\begin{array}{l}\text { Critical factors for the } \\
\text { successful } \\
\text { implementation of } \\
\text { business processes } \\
\text { (Rosemann \& de } \\
\text { Bruin, 2005) }\end{array}$ & $\begin{array}{l}\text { The most developed } \\
\text { factors of business } \\
\text { process management } \\
\text { maturity in } \\
\text { researched } \\
\text { companies }\end{array}$ & $\begin{array}{c}\text { Main lagging } \\
\text { factors of business } \\
\text { process } \\
\text { management } \\
\text { maturity in } \\
\text { researched } \\
\text { companies }\end{array}$ & $\begin{array}{c}\text { Factors with } \\
\text { greatest significance } \\
\text { individual } \\
\text { contribution to } \\
\text { business process } \\
\text { management } \\
\text { maturity }\end{array}$ \\
\hline Strategic alignment & $\begin{array}{c}\text { Standardisation of } \\
\text { processes }\end{array}$ & Strategic alignment & Managing employees \\
\hline Process management & $\begin{array}{c}\text { Continuous } \\
\text { improvement }\end{array}$ & $\begin{array}{l}\text { Appointment of } \\
\text { process owners }\end{array}$ & $\begin{array}{c}\text { Appointing process } \\
\text { owners }\end{array}$ \\
\hline Employee management & $\begin{array}{c}\text { Employees' } \\
\text { specialisation }\end{array}$ & $\begin{array}{l}\text { Managers' } \\
\text { commitment }\end{array}$ & Strategic alignment \\
\hline Methods & Methods & $\begin{array}{l}\text { Information } \\
\text { technology }\end{array}$ & Business culture \\
\hline Information technology & $\begin{array}{c}\text { Cooperation with } \\
\text { suppliers }\end{array}$ & Business culture & $\begin{array}{c}\text { Managers } \\
\text { commitment }\end{array}$ \\
\hline Culture & Managing employees & $\begin{array}{c}\text { Process } \\
\text { measurement } \\
\text { (Process } \\
\text { management) }\end{array}$ & $\begin{array}{l}\text { Focus on customers } \\
\text { and their } \\
\text { requirements }\end{array}$ \\
\hline
\end{tabular}

Source: Authors' calculation

Through usage of regression analysis, the influence of all of the observed factors to business process management maturity may be observed. The values of 16 factors were included in the model as independent variables. The business process management maturity was taken as a dependent variable. The beta coefficients show the influence each dimension has on the model, while significance has to be below the 0.05 . The null hypothesis assumes that all of the observed factors influence business process management maturity, while the alternative assumes that there is not influence of all of the observed factors to business process management maturity.

Starting from the value of the beta coefficient we compare the contribution of all maturity factors and found that the greatest individual contribution to business process management maturity has the factor Managing employees (beta $=2.613$ ). It means that Managing employees has the greatest individually contribution to the explanation of the business process management maturity, when subtract variance explained by all other maturity factors. Also, two more factors, belonging to the 
group of six dominant factors according to the Rosemann and de Bruin model, have significant individual contribution to business process management maturity (Strategic alignment (beta $=1.426)$ and Business culture $($ beta $=1.028)$ ). Also, we see that the factors which have the greatest individual contribution to the business processes maturity, at the same time, they are the main lagging maturity factors in observed companies.

Based on the observation of the table, it can be concluded that several business process management factors (IT investment, Process measurement (Process management), Methods, Employees' specialisation, etc.) have low, insignificant predicting power for the business process management maturity. These factors have significance level higher than 0.05 . Hence, it is important to emphasize that the obtained results can be the result of overlapping with other independent variables in the model. Based on the above, the null hypothesis is rejected, and the alternative is accepted. In this way third hypothesis is rejected, meaning that all of the observed factors do not influence business process management maturity.

Table 3. Regression analysis

\begin{tabular}{|c|c|c|c|c|c|}
\hline \multirow[t]{2}{*}{ Variables / Factors } & \multicolumn{2}{|c|}{$\begin{array}{l}\text { Unstandardised } \\
\text { Coefficients }\end{array}$} & \multirow{2}{*}{$\begin{array}{c}\begin{array}{c}\text { Standardised } \\
\text { Coefficients }\end{array} \\
\text { Beta } \\
\end{array}$} & \multirow[t]{2}{*}{$\mathbf{t}$} & \multirow[t]{2}{*}{ Sig. } \\
\hline & $\mathrm{B}$ & Std. Error & & & \\
\hline Strategic alignment & 1.001 & .374 & 1.426 & 2.676 & .023 \\
\hline IT investment & .427 & .339 & .440 & 1.261 & .236 \\
\hline $\begin{array}{l}\text { Process measurement (Process } \\
\text { management) }\end{array}$ & .276 & .252 & .386 & 1.094 & .299 \\
\hline Managing employees & 2.160 & .751 & 2.613 & 2.878 & .016 \\
\hline Organisational changes & -1.282 & .435 & -1.629 & -2.950 & .015 \\
\hline Appointing process owners & .974 & .422 & 1.512 & 2.312 & .043 \\
\hline Managers' commitment & .767 & .399 & .946 & 1.923 & .013 \\
\hline Continuous improvement & .521 & .271 & .493 & 1.922 & .014 \\
\hline Business culture & .875 & .298 & 1.028 & 2.939 & .015 \\
\hline IT & .435 & .157 & .518 & 2.764 & .020 \\
\hline Methods & -.032 & .325 & -.038 & -.098 & .924 \\
\hline Employees' specialisation & .234 & .276 & .246 & .849 & .416 \\
\hline $\begin{array}{l}\text { Focus on customers and their } \\
\text { requirements }\end{array}$ & .685 & .348 & .784 & 1.966 & .028 \\
\hline Standardisation of processes & .273 & .298 & .310 & .916 & .381 \\
\hline $\begin{array}{l}\text { Implementation of proposed } \\
\text { changes }\end{array}$ & .334 & .359 & .404 & .931 & .374 \\
\hline Cooperation with suppliers & .111 & .214 & .143 & .519 & .615 \\
\hline
\end{tabular}

Source: Authors' calculation 
Based on the correlation analysis, strength and direction of the connection between maturity factors was examined. According to the results of the correlation analysis, between some factors there is a strong positive correlation.

Table 4. Correlation analysis of the process management maturity factors

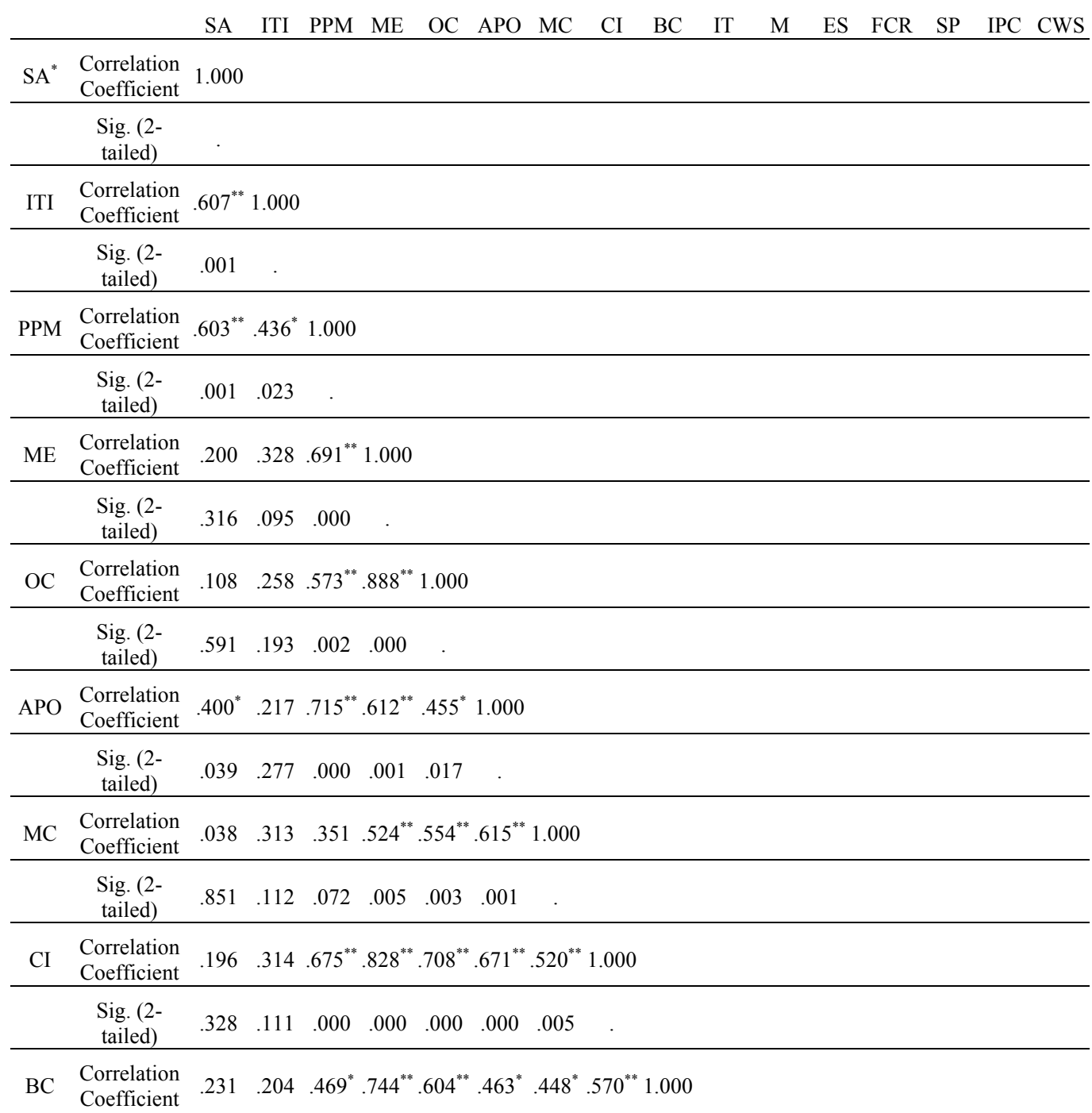

* Explanation of the used symbols: SA-Strategic alignment, ITI-IT investment, PPM-Process measurement (Process management), ME-Managing employees, OC-Organisational changes, APOAppointment of process owners, MC-Managers' commitment, CI-Continuous improvement, BCBusiness culture, IT-Information technology, M-Methods, ES-Employees' specialisation, FCR-Focus on customers and their requirements, SP-Standardisation of processes, IPC-Implementation of proposed changes, CWS-Cooperation with suppliers. 


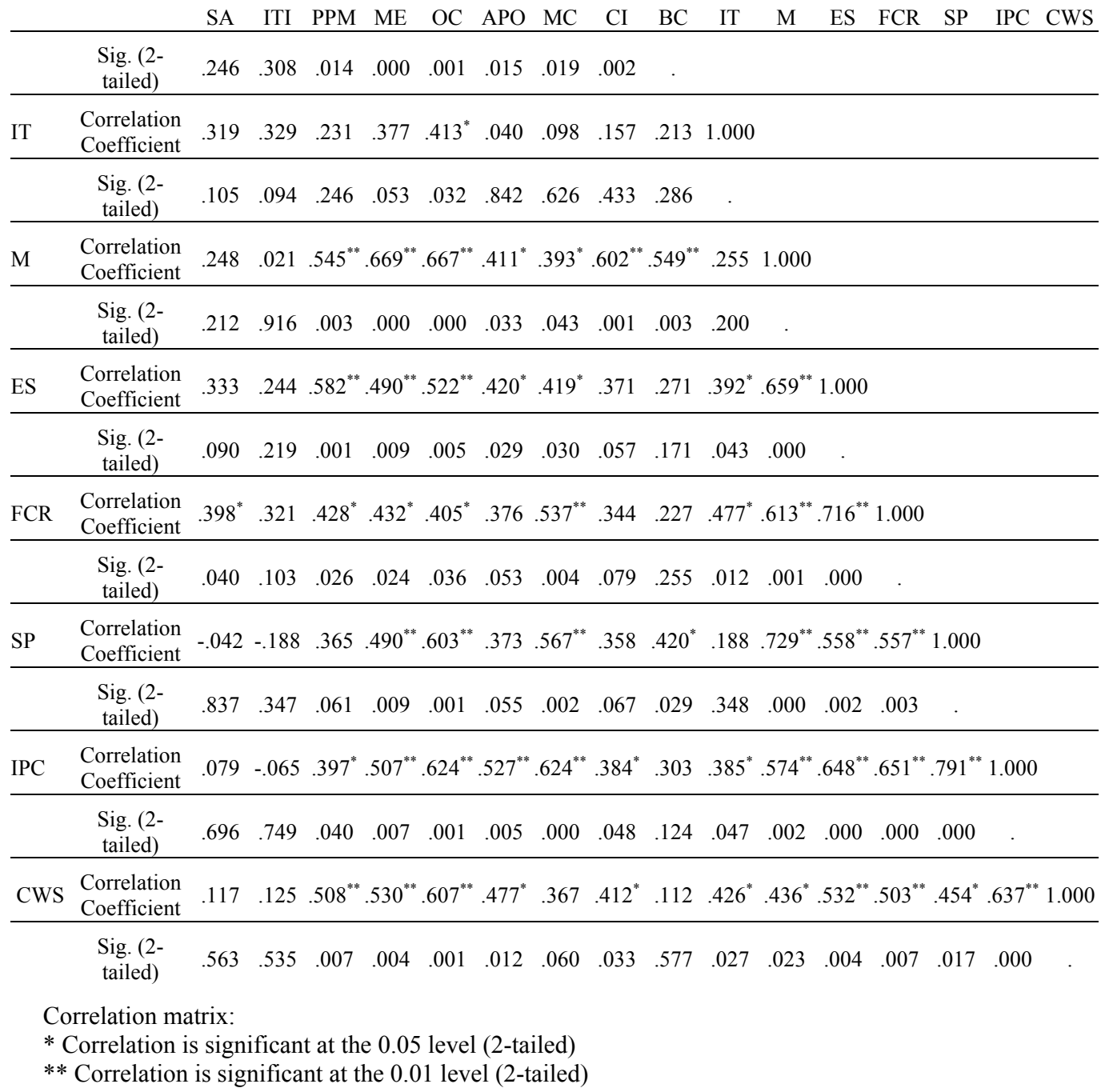

Source: Authors' calculation

More specifically, the results show that there is strongest statistically significant correlation between factors Organisational changes and Managing employees (correlation coefficient is 0.888). Based on calculated correlation coefficients observed existence of strong correlation between factors Continuous improvement and Managing employees (correlation coefficient is 0.828) and between Business culture and Managing employees (correlation coefficient is 0.744 ) It means that an increase in the maturity level of Managing employees is followed by an increase in the maturity levels of Organisational changes, Continuous improvement and Business culture. Also, concluded that Standardisation of processes strong positive 
correlated with factors Methods (correlation coefficient is 0.729) and Implementation of proposed changes (correlation coefficient is. 0.791).

Connection between the observed business process management factors and, therefore, possibility to use one of them as a driver for increasing the maturity level of the others, can also be seen from the dendrogram, presented in Figure 2.

Figure 2: Connection between the observed maturity factors*

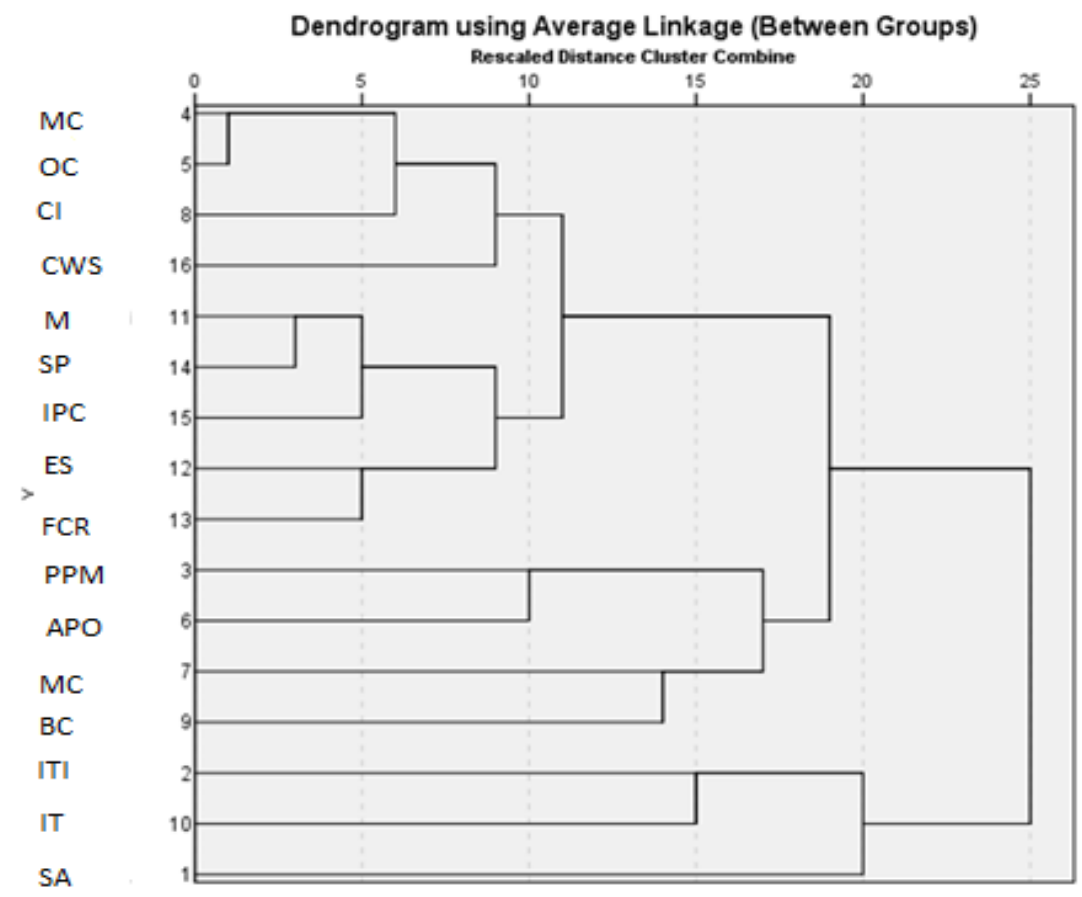

Figure 2 shows that the closest ones are variables (those variables are connected more than the others): Managing employees and Organisational changes, Methods and Standardisation of processes and Employees' specialisation and Focus on customers and their requirements.

In order to find drivers to achieve a higher level of business process management maturity, it is important to examine the correlation between maturity factors and business process management maturity. Based on results presented in Table 5, it can be said that there is the statistically significant strong correlation between Information technology and business process management maturity (correlation coefficient is 0.743 ).

\footnotetext{
* The explanation of the used symbols was given earlier
} 
Table 5. Correlation analysis of the maturity factors and business process management maturity

\begin{tabular}{|c|c|c|}
\hline \multirow[b]{2}{*}{ Strategic alignment } & Correlation Coefficient & $.503^{* *}$ \\
\hline & Sig. (2-tailed) & .007 \\
\hline \multirow[b]{2}{*}{ IT investment } & Correlation Coefficient & $.429^{*}$ \\
\hline & Sig. (2-tailed) & .026 \\
\hline \multirow[b]{2}{*}{ Process measurement (Process management) } & Correlation Coefficient & $.453^{*}$ \\
\hline & Sig. (2-tailed) & .018 \\
\hline \multirow[b]{2}{*}{ Managing employees } & Correlation Coefficient & $.511^{* *}$ \\
\hline & Sig. (2-tailed) & .006 \\
\hline \multirow[b]{2}{*}{ Organisational changes } & Correlation Coefficient & $.430^{*}$ \\
\hline & Sig. (2-tailed) & .025 \\
\hline \multirow[b]{2}{*}{ Appointing process owners } & Correlation Coefficient & .272 \\
\hline & Sig. (2-tailed) & .170 \\
\hline \multirow[b]{2}{*}{ Managers' commitment } & Correlation Coefficient & .148 \\
\hline & Sig. (2-tailed) & .461 \\
\hline \multirow[b]{2}{*}{ Continuous improvement } & Correlation Coefficient & $.471^{*}$ \\
\hline & Sig. (2-tailed) & .013 \\
\hline \multirow{2}{*}{ Business culture } & Correlation Coefficient & .252 \\
\hline & Sig. (2-tailed) & .205 \\
\hline \multirow[b]{2}{*}{ Information technology } & Correlation Coefficient & $.743^{* *}$ \\
\hline & Sig. (2-tailed) & .000 \\
\hline \multirow[b]{2}{*}{ Methods } & Correlation Coefficient & $.423^{*}$ \\
\hline & Sig. (2-tailed) & .028 \\
\hline \multirow[b]{2}{*}{ Employees' specialisation } & Correlation Coefficient & $.423^{*}$ \\
\hline & Sig. (2-tailed) & .028 \\
\hline \multirow[b]{2}{*}{ Focus on customers and their requirements } & Correlation Coefficient & $.478^{*}$ \\
\hline & Sig. (2-tailed) & .012 \\
\hline \multirow[b]{2}{*}{ Standardisation of processes } & Correlation Coefficient & .169 \\
\hline & Sig. (2-tailed) & .398 \\
\hline \multirow[b]{2}{*}{ Implementation of proposed changes } & Correlation Coefficient & .375 \\
\hline & Sig. (2-tailed) & .054 \\
\hline \multirow[b]{2}{*}{ Cooperation with suppliers } & Correlation Coefficient & $.429^{*}$ \\
\hline & Sig. (2-tailed) & .026 \\
\hline
\end{tabular}

Correlation matrix:

* Correlation is significant at the 0.05 level (2-tailed)

** Correlation is significant at the 0.01 level (2-tailed)

Source: Authors' calculation

Compared to the others, higher correlation coefficients with business process management maturity can be found for Managing employees (correlation coefficient is 0.511 ) and Strategic alignment (correlation coefficient is 0.503 ). For the factors that have the significance level higher than 0.05 , it can be concluded that there is no correlation between them and business process management maturity. 


\section{Conclusion}

For many organisations, improving business process management capabilities is one of the main topics. The achieved level of process maturity is conditioned by the development of the dominant factors of business process management maturity. In that sense, research of the achieved factors' business process management maturity is important.

The factors that are emphasised as the critical for increasing business process management maturity (Rosemann \& de Bruin, 2005) are not recognised as dominant in the presented research results. Based on those results, it is found that the most developed business process management factors are Standardisation of processes and Continuous improvement. In addition, these factors are not presented as critical in the mentioned model.

One of the findings of the survey reveals the limitations of further improvement of business process management maturity in the observed companies. Namely, the identified main lagging factors (Strategic alignment, Information technology, Business culture, Process measurement) in the model Rosemann and de Bruin (2005) are found as four of six the most important factors for the successful implementation of business processes.

The results of the correlation analysis show the existence of, stronger or weaker, correlation between a great number of maturity factors. The detection of a strong positive correlation between some maturity factors should serve as a guideline for electronics industry companies. It means that they should be aware that increase in the maturity level of Managing employees is followed by an increase in the maturity levels of Organisational changes, Continuous improvement and Business culture. For a more detailed analysis of established connections between maturity factors, dendrogram can be used and it shows that Managing employees provides synergy effects if change of factor Organisational changes is provided.

The results of correlation analysis show that achieving high maturity level of Information technology is followed by high state of business process management maturity. Also, Strategic alignment and Managing employees have strong positive correlation with business process management maturity.

The influence of the observed factors on business process management maturity may be evaluated based on regression analysis. Managing employees has greatest individual contribution to business process management maturity. This factor is one of most developed factors in researched companies and between it and maturity business process management is significant strong positive correlation. Also, Managing employees has strong correlation with other maturity factors (Organisational changes, Continuous improvement, Business culture, etc.). According to that, this factor can be considered as critical for electronic industry improvement. 
This paper is an attempt to identify the key factors of the achieved level of business process management development in electronics industry. The authors tried to determine if they are matched with maturity factors that are marked as critical in the Roseman and de Bruin model (2005). One of the maturity factors (Managing employees) deserves special manager's attention, based on the degree of development, strength of correlation with other factors and in terms of contribution to increasing the maturity of business process management. The main recommendation for managers in the electronic industry refer to the necessity of improving the main lagging maturity factors, as they are marked as factors with a significant contribution to increasing the maturity of business process management.

For further research in the field of business process management maturity, a wide framework of business process management factors can be used. By applying this set of maturity factors framework in selected industrial areas in our country, it would be possible to compare the identified critical factors and the achieved level of business process management maturity in order to create a framework of factors characteristic for developing countries.

\section{References}

Adamides, E.D. \& Karacapilidis, N. (2006). A knowledge centred framework for collaborative business process modelling. Business Process Management Journal, 5, 557-575.

Alibabaei, A., Aghdasi, M., Zarei, B., \& Stewart, G. (2010). The role of culture in business process management initiatives. Australian Journal of Basic and Applied Sciences, 4, 2143-2154. Retrieved from: http://eprints.qut.edu.au/43250/, Assessed on 11. November 2017.

Andersen, B. (1999). Business Process Improvement Toolbox. Milwaukee: ASQ Quality Press.

Bai,Ch. \& Sarkis, J. (2013). A grey-based DEMATEL model for evaluating business process management critical success factors. International Journal of Production Economics, 146 (1), 281-292

Bandara, W., Alibabaei, A. \& Aghdasi, M. (2009). Means of achieving Business Process Management success factors. In: Proceedings of the 4th Mediterranean Conference on Information Systems, Athens University of Economics and Business, Athens.

Benner,M. J. \& Tushman, M. L. (2003). Exploitation, exploration, and process management: The productivity dilemma revisited. The Academy of Management Review, 28(2), 238-256.

Bosilj-Vukšić, V., Spremić, M., Omazić, M.A., Vidović, M. \& Hernaus, T. (2006). Menadžment poslovnih procesa i znanja u hrvatskim poduzećima. EFZG working paper series, (05), 1-20.

Cantista, I. \& Tylecote, A. (2008). Industrial Innovation, Corporate Governance and SupplierCustomer Relationships. Journal of Manufacturing Technology Management, 19(5), 516-590. 
Chae, B., Yen, H. R., \& Sheu, C. (2005). Information technology and supply chain collaboration: Moderating effects of existing relationships between partners. IEEE Transactions on Engineering Management, 52(4), 440-448.

Chen, I.J. (2001). Planning for ERP systems: analysis and future trend. Business Process Management Journal, 7(5), 374-86.

Duh, R.-R., Chow, C. W. \& Chen, H. (2006). Strategy, IT applications for planning and control, and firm performance: The impact of impediments to IT implementation. Information \& Management, 43(8), 939-949.

Erl, T. (2005) Service-oriented architecture concepts, technology and design. Upper Saddle River. NJ: Pearson Education.

Fisher, D.M. (2004). The Business Process Maturity Model-A Practical Approach for Identifying Opportunities for Optimization. Bearing Point, Inc. Retrieved from: http://www.bptrends.com/publicationfiles/1004\%20ART\%20BP\%20Maturity\%20Mo del\%20-\%20Fisher.pdf, Assessed on 10. December 2017.

Garimella, K., Lees, M. \& Williams, B. (2008). BPM Basics for Dummies. Software AG Special Edition. Wiley Publishing, Inc., Indiana: Indianapolis.

Hall, J. M. \& Johnson, M. E. (2009). When should a process be art, not science?. Harvard Business Review, (March), 59-65.

Hammer, M., \& Stanton, S. (1999) How process enterprises really work. Harvard Business Review, 77(6), 108-118.

Harmon, P. (2003). Business process change: A manager's guide to improving, redesigning and automating processes. San Francisco: Morgan Kaufmann.

Harmon, P. (2014). Business Process Change.: A Business Process Management Guide for Managers and Process Professionals ( $3^{\text {nd }}$ ed). Burlington: Morgan Kaufmann.

Hassan, N. R. (2009). Using social network analysis to measure IT-enabled business process performance, Information Systems Management, 26(1), 61-76

Herzig, S. E. \& Jimmieson, N. L. (2006). Middle managers' uncertainty management during organizational change. Leadership \& Organization Development Journal, 27(8), 628645.

Hiemstra,A. Ravesteyn,P \& Versendaal J. (2009). An alignment model for business process management and service oriented architecture. In: $6^{\text {th }}$ intenational conference on enterprice,systems, accounting and logistics.

Jarrar, Y. F., Al-Mudimigh, A. \& Zairi, M. (2000). ERP implementation critical success factors-the role and impact of business process management. In Management of Innovation and Technology, ICMIT 2000.1, 122-127.

Jeston, J. \& Nelis, J. (2014). Business process management. New York: Routledge.

Koster, S. (2009). An evaluation method for Business Process Management products. Graduation thesis. Business Information Technology. University of Twente. Netherlans

Küng, P. \& Hagen, C. (2007). The fruits of business process management: An experience report from a Swiss bank. Business Process Management Journal, 13(4), 477-487.

Lahajnar, S. \& Rožanec, A. (2016). The evaluation framework for business process management methodologies. Management, 21(1), 47-69.

Leavitt, H. (2005). Top down: Why hierarchies are here to stay and how to manage them more effectively. Boston: Harvard Business School Press.

Madison J. D. (2005). Process Mapping, Process Improvement and Process Mangement - A Practical Guide to Enhancing Work and Information Flow. Chico: Paton Press. 
Melenovsky, M.J. \& Sinur, J. (2006). BPM maturity model identifies six phases for successful BPM adoption, Gartner Research, ID No: G00142643 18 October.

Melville,N., Kraemer,K. \& Gurbaxani,V. (2004). Information technology and organizational performance: An integrative model of IT business value. MIS Quarterly, 28(2), 283-322.

Mulyar, N. \& van der Aalst, W. M. P. (2005). Towards a pattern language for colored Petri nets. Paper presented at the sixth workshop and tutorial on practical use of coloured Petri nets and the CPN tools. Retrieved from: http://www.pads.rwthaachen.de/wvdaalst/publications/p288.pdf, Assessed on 20. November 2017.

Ngai, E. W. T., Law, C. C. H., \& Wat, F. K. T. (2008). Examining the critical success actors in the adoption of enterprise resource planning. Computers in Industry, 59(6), 48-564.

Radosavljević, M. (2015). Process Orientation as a Basis for increasing supply chain Management Maturity. Economic Themes, 53(3), 398-414.

Ravesteyn, P. \& Batenburg, R. (2010). Surveying the critical success factors of BPM-systems implementation. Business Process Management Journal,16(3), 492-507.

Ravesteyn, P. \& Versendaal, J. (2007). Success factors of business process management systems implementation. ACIS Proceedings, 60, 396-406.

Reijers, H. A. \& Mansar, L. (2005). Best practices in business process redesign: An overview and qualitative evaluation of successful redesign heuristics. Omega, 33(4), 283-306

Rhee, M. \& Mehra, S. (2006). Aligning operations, marketing, and competitive strategies to enhance performance: An empirical test in the retail banking industry. Omega, 34(5), 505-515.

Roberts, EB. (2001). Benchmarking Global Strategic Management of Technology. Res. Technol. Manage, 44(2), 25-36.

Rosemann, M. \& De Bruin, T. (2005a) Application of a Holistic Model for Determining BPM Maturity.BPTrends, p. 1-20.

Rosemann, M. \& De BruinT. (2005b).Toward s a Business Process Management Maturity Model. 13th European Conference on Information Systems (ECIS 2005), Regensburg, Germany.

Rosemann, M. (2006). Potential pitfalls of process modeling: part A. Business Process Management Journal, 12 (2), 249-254.

Rosemann, M. \& vom Brocke, J. (2010). The six core elements of business process management. In: vom Brocke, J. \& Rosemann, M. (Eds.), Handbook on business process management, Introduction, methods and information systems 1, 109-124, Springer, Berlin.

Savolainen, T. I. (1999). Cycles of continuous improvement: Realizing competitive advantages through quality. International Journal of Operations \& Production Management, 19(11), 1203-1222.

Sharp, A. \& McDermott, P. (2009). Workflow modelling: tools for process improvement and applications development. Norwood: Artech House, MA.

Sikavica, P., \& Hernaus, T. (2011). Dizajniranje organizacije. Novi informator, Zagreb.

Silvestro, R. \& Westley, C. (2002). Challenging the paradigm of the process enterprise: A case-study analysis of BPR implementation. Omega, 30(3), 215-225.

Štemberger, M. I., Bosilj-Vukšić, V., \& Jaklić, M. I. (2009). Business process management software selection-two case studies. Economic research - Ekonomska istraživanja, 22(4), 84-99. 
Terziovski, M., Fitzpatrick, P. \& O’Neill, P. (2003). Successful predictors of business process reengineering (BPR) in financial services. International Journal of Production Economics, 84(1), 35-50.

Trkman, P. \& McCormack, K. (2010). Estimating the benefits and risks of implementing eprocurement. IEEE Transactions on Engineering Management, 57(2), 338-349.

Trkman, P. (2010). The critical success factors of business process management. International journal of information management, 30(2), 125-134.

Valle S, \& Vázquez Bustelo, D. (2009). Involving suppliers in new product development: An Analysis of Spanish Firms. Universia Bus. Rev., 24, 62-75.

vom Brocke, J. \& Schmiedel, T. (2011). Towards a conceptualisation of BPM culture: Results from a literature review.15th Pacific Asia Conference on Information Systems, Brisbane, Australia: In PACIS Proceedings. Retrieved from: https://webdocs.uni.li/public/03805967.PDF, Assessed on 10. December 2017.

Weske, M. (2007). Business process management. Concepts, languages and architectures. Berlin Heidelberg, Springer.

\section{IDENTIFIKACIJA I ANALIZA KLJUČNIH FAKTORA UPRAVLJANJA POSLOVNIM PROCESIMA}

Rezime: U uslovima sve oštrije konkurencije na tržištu, kompanije mogu ostvariti konkurentsku prednost jedino bržom ponudom kvalitetnijih i jeftinijih proizvoda/usulga. U tom cilju, kompanije moraju izvršavati inovativne i delotvorne poslovne procese i upravljati njima adekvatno. U tom smislu, značajno je identifikovati faktore koji se mogu smatrati kritičnim za poboljšanje upravljanja poslovnim procesima. Cilj ovog rada je identifikacija i analiza ključnih faktora upravljanja poslovnim procesima u jednoj od zemalja u razvoju, na primeru elektronske industrije. Rezultati istraživanja pokazuju da faktori koji su obično prihvaćeni kao najvažniji za povećanje zrelosti upravljanja poslovnim procesima nisu prepoznati kao dominantni u okviru elektronske industrije. Jedan od zaključaka istraživanja otkriva kao glavne zaostajuce faktore četiri od šest najvažnijih faktora za uspešnu implementaciju poslovnih procesa. Na osnovu rezultata istraživanja, kao najznačajniji faktor zrelosti za kompanije iz oblasti elektronske industrije otkriveno je Upravljanje zaposlenima, stoga je predlog dalje unapređenje u ovoj oblasti.

Ključne reči: procesna orijentacija, upravljanje poslovnim procesima, faktori zrelosti, elektronska industrija 


\section{Authors' biographies}

Aleksandra Stoiljković Randjelović is a $\mathrm{PhD}$ student at the Faculty of Economics, University of Nis, module Finance and Banking. In 2007, she graduated from the Faculty of Economic in Nis and in 2012 defended her Master's thesis at the Faculty of Economics in Nis, as well. Now she is working on a doctoral dissertation in the field of process management.Her key interest areas are the following: banking, risk management, process management, human resource management.

Radenko Milojević is a full-time professor at the Faculty of Economics, University of Niš, for narrow scientific field Business management. He is a lecturer for the following courses: Business resource management, Human Resources Management, Agency Business, International Human Resource Management, Business Process Management. He completed his undergraduate studies at the Faculty of Economics in Kragujevac, graduate at the Faculty of Economics in Belgrade, and he defended his doctoral thesis at the Faculty of Economics in Subotica. The key areas of his interest are: functioning of the enterprise, human resources management, business process management.

Marija Radosavljević is an Associate Professor at the Faculty of Economics, University of Nis, for narrow scientific field business management. In 2001, she graduated from the Faculty of Economic in Nis as a student of generation and defended her Master's and doctoral thesis at the Faculty of Economics in Belgrade in 2004 and 2009, respectively. She has participated in a few projects, financed by the Ministry of Science of Republic of Serbia. In 2005, 2009 and 2011 she was engaged as a researcher at the University for Economics and Business Administration, Department for Production Management, Wien, Austria and in 2013 as a visiting professor at Willamette University, Atkinson Graduate School of Management, Oregon, the US, as the only candidate from Serbia. Her key interest areas are: quality management, process management, cost management, human resource management. So far, she has published more than 130 papers in journals and proceedings from the conferences (national and international) and 5 monographs. 